\title{
衣服のイメージ評価におけるばらつきの処理方法
}

\author{
武庫川女子大学 磯井 佳子・風間 健 \\ 神戸芸術工科大学 小田 順子
}

\section{Considerration about the Variation of Evaluation on Image of Clothes}

Keiko lsoi, ${ }^{* 1}$ Jyunko Oda, ${ }^{* 2}$ and Ken Kazama*1

* ${ }^{1}$ Faculty of Home Economics, Mukogawa Women's University, Ikebiraki Nishinomiya, Hyougo Pref., 663 Japan

* 2 Department of Industrial Design, Kobe Design University, Kobe, Hyougo Pref., 673. Japan

\begin{abstract}
Variation in evaluating fashion clothes was statistically evaluated. Three experts evaluated fifty clothes twice using thirty image words. These evaluated values were classified into agreements and disagreements by using a statistical test. The evaluated words and clothes were classified into the main effects and the interactions by using Suryoka III. The evaluated criteria were obtained by using the correlation matrix and factor analysis.
\end{abstract}

(Received December 24, 1991)

\section{1. 藉 垔}

ファッション衣料のイメージ評価においては,ファッ ションの専門家と言えども結果がばらつくことを，筆者 らはすでに明らかにした[1-4]。ばらつきが存在する以 上,ばらつきの中から評価結果を抽出し, 判定者の基準 を得る方法を確立する必要がある。そこで本研究では， このようなばらつきのある判定値の処理方法を見いだす と共に，その方法を用いて曹門家の判定基準を求め，判 定の結果を知ることを目的にする。この目的を達成する ために，専門家を判定者とし，その判定結果を用いてば らつきの性格を明らかにする。

\section{2. 方 法}

\section{1 判定者}

判定者は，3名のファッション衣料に関する女性の専 門家である。それぞれ専門は婦人服のデザイナ一,コー ディネーター,マーケターで, 年齡は20代，40代，60代 である。

\section{2 判定方法}

従来の文献[2,5-7]にあらわれた 30 種類のイメージ用 語を，対にせずに用いて 50 着の衣服を評価する。評価は
1「そう思う」から5「違うと思う」までの5 段階とする。 30種類のイメージ用語を表 1 に示す。衣服は，最近のフ アッション雑誌から選んだ外出用の20才代の婦人服に関 する写真である。各判定者は，1吕月执いて 2 回の評侕

Table 1 Words for Describing Image of Clothes

\begin{tabular}{clcl}
\hline No. & \multicolumn{1}{c}{ Words } & No. & \multicolumn{1}{c}{ Words } \\
\hline 1 & Good sence of & 16 & Playful \\
2 & Romantic & 17 & Rich \\
3 & Basic & 18 & Fashionable \\
4 & Casual & 19 & Decorative \\
5 & Refined & 20 & Soft \\
6 & Pretty & 21 & Mannish \\
7 & In good taste & 22 & Conservative \\
8 & Adult & 23 & Well-Coordinated \\
9 & Simple & 24 & Modern \\
10 & Classic & 25 & Well-dressed \\
11 & Sexy & 26 & Feminine \\
12 & Sharp & 27 & Chic \\
13 & Trendy & 28 & Graceful \\
14 & Elegant & 29 & Sporty \\
15 & Womanly & 30 & Youthful \\
\hline
\end{tabular}


Table 2 The Frequency Distribution on the Agreed Results by Statistical Test

\begin{tabular}{lccccccccccc}
\hline \multicolumn{1}{c}{ Clothes } \\
\hline $\begin{array}{l}\text { Number of } \\
\text { agreement }\end{array}$ & $0-5$ & $6-10$ & $11-15$ & $16-20$ & $21-30$ & $0-19$ & $20-24$ & $25-29$ & $30-34$ & $35-50$ \\
\hline Frequency & 1 & 6 & 18 & 19 & 6 & 5 & 8 & 6 & 7 & 4 \\
\hline
\end{tabular}

Table 3 The Concept of Suryoka III (Agree, Factor 1)

\begin{tabular}{|c|c|c|c|c|c|c|c|c|c|}
\hline \multirow{2}{*}{ Clothes } & \multicolumn{8}{|c|}{ Words } & \multirow{2}{*}{$\begin{array}{l}\text { Quantitative } \\
\text { value }\left(10^{-1}\right)\end{array}$} \\
\hline & 13 & 23 & 18 & 3 & 21 & 8 & 14 & 10 & \\
\hline 29 & 1 & 1 & 1 & 1 & 0 & 0 & 0 & 0 & 0.29 \\
\hline 42 & 1 & 1 & 1 & 1 & 1 & 0 & 0 & 0 & 0.25 \\
\hline 38 & 0 & 0 & 0 & 1 & 0 & 1 & 1 & 1 & -0.23 \\
\hline 22 & 0 & 0 & 0 & 1 & 0 & 1 & 1 & 1 & -0.30 \\
\hline $\begin{array}{l}\text { Quantitative } \\
\text { value }\left(10^{-1}\right)\end{array}$ & 0.90 & 0.71 & 0.59 & -0.07 & -0.04 & -0.52 & -0.61 & -0.76 & \\
\hline
\end{tabular}

を行い, 衣服と用語の全租合せにそれぞれ 6 個の判定値 が得られた。

\section{3. 考察}

\section{1 一致性の判定}

6 個の判定值を, 一致した結果と不一致の結果とに次 の検定方法で分類する。

6 個の判定值 $\mathrm{x}_{\mathrm{i}}(\mathrm{i}=1,2, \cdots \cdot 6)$ のうち, その平均 $\overline{\mathrm{x}}$ から 1 点以内にはいる判定颠が 5 個以上である( 1 個以 下が 1 点以上離れる)場合，これを「一致」とし，それ以 外を「不一致」とする。判定值が正规分布をすれば，上記 の一致の条件は次式で表される。

$\mathrm{P}_{\mathrm{r}}\left|\left(\mathrm{x}_{\mathrm{i}}-\overline{\mathrm{x}}\right) / \mathrm{s}\right| \leqq 1 / 6$

ここに $\mathrm{P}_{\mathrm{r}}$ は確率， $\mathrm{s}$ は 6 個の判定値の標準偏差(不偏分 散の平方根)である。片側で1/6になる正規化值は 0.965 , 式 1 の分子は前述の「一致」の定義から 1 なの c.,

$$
1 / \mathrm{s} \leqq 0.965
$$

となり $s=\leqq 1.036 か ゙$ 得られる。すなわち 6 個の判定値 の標染偏差が1.036以下ならば判定が一致したとする。

用語 30 と衣服 50 の全組合せ 1500 のち，一致が788, 不一致が712であった。

\section{2 判定結果の考察}

\section{(1)一致しやすい用語と衣服}

個々の用語と衣服について，一致した判定が何件ある のかを度数分布で表 2 に示す。30用語のうち，50着中35 着以上で一致したものは 4 件で, 一致が19着以下は 5 件
であった。35着及び19着の基準は, 全洋服50着の両側 10\%とした。これらの用語を次に示寸。

一致した用語：ベーシックな, カジュアルな,かわい い, スポーティーな

不一致の用語：クラッシックな, トレンディーな,コ ンサバティブな，コーディネートがうまい，着こなしが うまい

この結果から，次のことが分かる。よく一致した用語 は，基準に客観性のあるベーシックな，カジュアルな と、イメージの明確なかかいい，スポーティな等があ る。不一致の用語は，流行(時間的变化)に関係あるるの と，価値評洒(うまいー下手)に関係するものである。 また一致しやすい衣服 6 件は，多くの用語に対してイ メージが明確で, 流行や価值評洒の判断も容易なもので あった。

(2)用語と衣服の交互作用

前項(1)は，多くの衣服に共通した一致しやすい用語 や，多くの用語に一致しやすい衣服を考えた。これは用 語や衣服の主効果と言える。これに対して，一致しにく い用語のうち，特定の衣服にはよく一致するが，それ以 外には一致しない用語がある。これらは衣服と交互作用 のある用語と言える。

これらを数量化類を用いて明らかにする。

インプットデータは，前項の検定の結果，一致した用 語と衣服の組合せを 1 ，不一致の組合せを 0 と置き，用 語をカテゴリー，衣服をサンプルとした。

数量化回類は，カテゴリーとサンプルに，相関係数が 
Table 4 Summary of Suryoka III (Quantitative value assigned to categories)

\begin{tabular}{|c|c|c|c|c|c|c|}
\hline \multirow[b]{2}{*}{ Factor } & \multicolumn{3}{|c|}{ Agree } & \multicolumn{3}{|c|}{ Disagree } \\
\hline & $\begin{array}{l}\text { Eigen- } \\
\text { values }\end{array}$ & Words & $\begin{array}{l}\text { Quantitative } \\
\text { value }\end{array}$ & $\begin{array}{l}\text { Eigen- } \\
\text { values }\end{array}$ & Words & $\begin{array}{l}\text { Quantitative } \\
\text { value }\end{array}$ \\
\hline \multirow{10}{*}{ I } & \multirow{10}{*}{0.34} & Trendy & 0.0899 & \multirow{10}{*}{0.37} & Sporty & 0.0948 \\
\hline & & Well-Coordinated & 0.0712 & & Modern & 0.0588 \\
\hline & & Fashionable & 0.0585 & & & \\
\hline & & Good sence of & 0.0560 & & & \\
\hline & & Modern & 0.0519 & & & \\
\hline & & Adult & -0.0524 & & Graceful & -0.0591 \\
\hline & & Elegant & -0.0613 & & Adult & -0.0621 \\
\hline & & Classic & -0.0756 & & Elegant & -0.0701 \\
\hline & & & & & Decorative & -0.0704 \\
\hline & & & & & Pretty & -0.0714 \\
\hline \multirow{6}{*}{ II } & \multirow{6}{*}{0.31} & In good taste & 0.0818 & \multirow{6}{*}{0.34} & Fashionable & 0.0691 \\
\hline & & Simple & 0.0629 & & Sexy & 0.0575 \\
\hline & & Classic & 0.0574 & & Sharp & 0.0521 \\
\hline & & Womanly & -0.0525 & & Soft & -0.0528 \\
\hline & & Elegant & -0.0593 & & Basic & -0.0759 \\
\hline & & Sexy & -0.0689 & & Sporty & -0.0942 \\
\hline \multirow{9}{*}{ III } & \multirow{9}{*}{0.28} & Well-dressed & 0.1006 & \multirow{9}{*}{0.32} & Basic & 0.0954 \\
\hline & & Well-Coordinated & 0.0758 & & Decorative & 0.0438 \\
\hline & & Adult & 0.0560 & & Well-dressed & 0.0402 \\
\hline & & Good sence of & 0.0533 & & & \\
\hline & & Modern & -0.0590 & & Mannish & -0.0560 \\
\hline & & Sporty & -0.0657 & & Pretty & -0.0586 \\
\hline & & & & & Sporty & -0.0782 \\
\hline & & & & & Casual & -0.0892 \\
\hline & & & & & Womanly & -0.1003 \\
\hline
\end{tabular}

最大となるような数量値を与える。この意味を表 3 によ り説明する。

用語群「13. トレンディーな，23，コーディネートが うまい, 18.ファッショナフルな,」(左端)は，衣服群

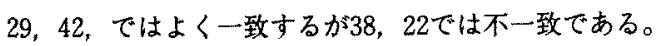
用語群「 8. 大人っほい，14.エレガントな，10．クラ ッシックな」(右端)は逆である。一方，「3，ベーシック な, 21. マニッシュな」は衣服群と無関係である。数量 値は無関係なものに低く，衣服群により歴然と变わるも のに高く付けられる。逆の関係にある群は，数量值の符 号が逆になる。「ベーシックな」は，前項で述べたように 主効果のある(39着で一致している)用語なので, 数量值 はほぼ0をとり，交互作用が表れない。

次に1と○を逆にしてインプットすると，不一致の用 語群、衣服群が得られる。この場合は前項で述べた主効 果の用語が「クラッシックな,トレンディーな」他にな
クこれらの数量值は，小さくなり0に近づく。一方， 一致の主効果用語(例えばベーシックな)は，一致しなか った少数の衣服が1になりここに注目して分類され る。これらの用語は, 用語軸の右端または左端に位置 し，数量値の絶対值は大きくなり $0.1 に$ 近づく。したが って一致と不一致では, 異なった結果が得られる。西者 の数量值の絶対值が大きいものを表 4 にあげ，併せて数 量値と固有値を示す。

表 4 の各因子は次の上うに解釈される。一致した場 合, 判定者の着眼点は，1因子が流行・センス，2因子 が女らしさ，3因子が年跲にある[2]。不一致の場合 は, 1 因子が装飾性，2因子がファッション志向，3因 子が活動性である。このように数量化四類は，一致と不 一致の着眼点を別に考える。

(3)一致した判定の評価基準

一致した衣服と用語の組合せについては，平均値を求 
Table 5 Evaluation Criteria Based on Each Average of the Agreed Ratings by Factor Analysis

\begin{tabular}{|c|c|c|c|}
\hline Factor & I & II & III \\
\hline $\begin{array}{l}\text { Cumulative } \\
\text { contribution }\end{array}$ & $30.30 \%$ & $58.04 \%$ & $75.06 \%$ \\
\hline 10 & 0.9308 & -0.0716 & -0.1825 \\
\hline 27 & 0.9066 & 0.0355 & 0.0679 \\
\hline 3 & 0.8751 & 0.0099 & 0.2325 \\
\hline 9 & 0.8736 & 0.1433 & 0.2665 \\
\hline 5 & 0.7536 & -0.4059 & -0.0783 \\
\hline $1 \cdot 7 \cdot 24 \cdot 23 \cdot 25$ & 0.6748 & 0.0532 & 0.6171 \\
\hline 19 & -0.4214 & -0.7372 & -0.1338 \\
\hline 11 & -0.5052 & -0.1077 & 0.7584 \\
\hline 21 & 0.3060 & 0.4964 & 0.8072 \\
\hline 6 & 0.1706 & -0.7238 & 0.1603 \\
\hline 19 & -0.4214 & -0.7372 & -0.1338 \\
\hline 28 & -0.0117 & -0.8509 & 0.1381 \\
\hline 20 & 0.0886 & -0.8565 & 0.0080 \\
\hline 14 & 0.0879 & -0.9664 & 0.0603 \\
\hline 2 & 0.0380 & -0.9801 & 0.0496 \\
\hline 15 & 0.0632 & -0.9930 & -0.0855 \\
\hline 13 & 0.0114 & -0.0623 & 0.9931 \\
\hline 12 & 0.2459 & -0.0068 & 0.8475 \\
\hline $4 \cdot 21 \cdot 29$ & 0.3060 & 0.4964 & 0.8072 \\
\hline 18 & 0.0130 & -0.1048 & 0.7899 \\
\hline 11 & -0.5052 & -0.1077 & 0.7584 \\
\hline 30 & 0.2043 & -0.1510 & 0.7276 \\
\hline $1 \cdot 7 \cdot 24 \cdot 23 \cdot 25$ & 0.6748 & 0.0532 & 0.6171 \\
\hline
\end{tabular}

めることができる。一致しない判定は，平均值が意味を 持たない。そこで不一致データを除いて，判定の基準を 求めるため, 次の方法を工夫した。

すなわち30の用語につき2つずつの全組合せを作り， それぞれの組合せについて再方に一致データのある場合 のみの相関係数を求める。いずれか一方が不一致 $(0)$ の 場合浪代していくわ忛である。こうして一致した衣服 と用語の組合せにつき，6個の判定值の平均值の相関保 数を求める。得られた相関行列をインプットデータとし て因子分析を行い，表 5 が得られた。得られた結果は， 一致したデータのみから求められた評価基準なので，従 来の全てのデータから求めた結果より, 物理的な意味が
明らかである。1因子は成熟した趣味のよさを，2因子 は女性らしさを，3因子は流行を評価基準としているこ とを示す。

\section{4. 結䤅}

ファッション衣料のイメージ評価の際, 必然的に発生 するばらつきにつき，その処理方法を導いた。

1. 判定者の判定值が一致しているか, 不一致かの検定 方法を定め，その結果に基づいて全ての判定値を一致と 不一致に分類した。

2．上記の一致した判定結果を用いて，(1)多くの衣服に ついて一致した用唔は，用語の主効果がある。このよう な用語を求めた。衣服についても同様である。(2)多くの 用語について一致または不一致の衣服を，度数分布から 求めることができる。

3.一方，衣服によって一致したり不一致になったりす る用語は，衣服と交互作用のある用語である。このよう な用語を求めた。用語と交互作用のある衣服も同様であ る。

4.一致した判定のみを用いて，判定者の評価基準を推 定する方法を導き， 3 種類の基準を得た。

\section{謝辞}

本研究の実施に際して，専門家として判定及び教示を いただいた清松久代(捇エイム)，東野里美の両氏に深く 感謝する。

\section{文献}

1. 磯井佳子, 小田順子, 風間 健, 絨学誌, 45, 223 (1989).

2. 磯井佳子, 小田順子, 風間 健, ファッション環学 誌, 1, 12(1992).

3. 磯井佳子, 小田順子, 風間 揵, 驖維学会昭和63年 年次大会研究発表会講演要旨集, p.B-170(1988).

4, 磯井佳子, 小田順子，風間 健，誡維学会平成 2 年 年次大会研究発表講演会要旨集, p.B-50 (1990).

5. 磯井佳子，風間 健，峨学誌，45，35(1989).

6. 藤原康晴, 川端澄子，近藤信子，家政誌，41，241 (1990).

7. 川崎健太郎, 河本直樹, 栈消誌, 32, 217(1991). 